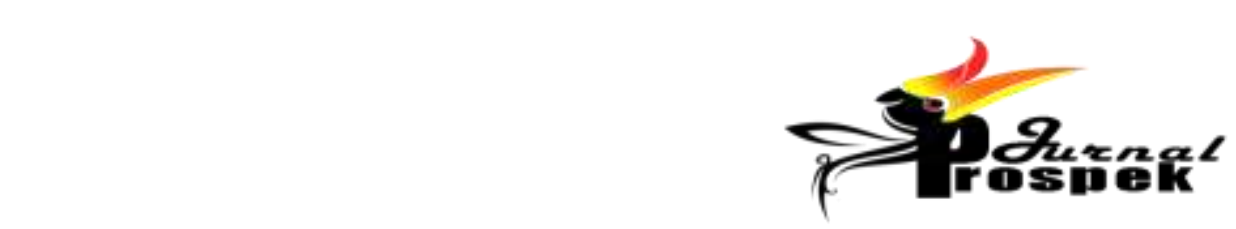

http://e-journals.unmul.ac.id/index.php/jpe

Jurnal Prospek : Pendidikan Ilmu Sosial dan Ekonomi

Volume 3 No 1 Juli 2021

E-ISSN 2721-0855

\title{
HUBUNGAN KAPABILITAS PROMOSI JABATAN DENGAN RODUKTIVITAS KERJA KARYAWAN PADA PT. NUNUKAN BARA SUKSESTAHUN 2020
}

\author{
Kristina \\ Univeritas Mulawarman \\ Yiitina11@gmail.com \\ Made Ngurah Partha \\ Universitas Mulawarman \\ Rahdee24@gmail.com \\ Noor Ellyawati \\ Universitas Mulawarman \\ ellymimo@yahoo.com
}

\begin{abstract}
The type of research used is quantitative. The population in this study are employees of PT. Nunukan Bara Sukses as many as 105 employees. Data collection techniques in this study were observation, documentation, interviews, and questionnaire. Product moment research results In the test $r$ obtained from the results of the study, the number of employees who were the subjects were 77 respondents. The conclusion of the research is that job promotions can be qualified at a good level in accordance with the ability of employees so that they can provide motivation and enthusiasm to work better and employee productivity is qualified at a good level, because it is in line with the company's vision and mission to prioritize employees who excel.
\end{abstract}

Keywords: position promotion, work productivity

\begin{abstract}
AbstrakJenis penelitian digunakan adalah kuantitatif. Populasi dalam penelitian ini adalah karyawan perusahaan PT. Nunukan Bara Sukses sebanyak 105 karyawan. Teknik pengumpulan data dalam penelitian ini adalah observasi, dokumentasi, wawancara, dan kusioner.Hasil penelitian product moment Didalam uji $\mathrm{r}$ didapatkandari hasil penelitian, jumlah karyawan yang menjadi subyek sebanyak 77 responden. Kesimpulan hasil penelitian bahwa promosi jabatan dapat dikualifikasikan pada tingkat yang baik sesuai dengan kemampuan karyawan sehingga dapat memberikan motivasi dan semangat kerja untuk bekerja lebih baik dan produktivitas kerja karyawan dikualifikasikan pada tingkat baik, karena sejalan dengan visi misi perusahaan untuk mengutamakan karyawan yang berprestasi.
\end{abstract}

Kata Kunci : promosi jabatan, produktivitas kerja 


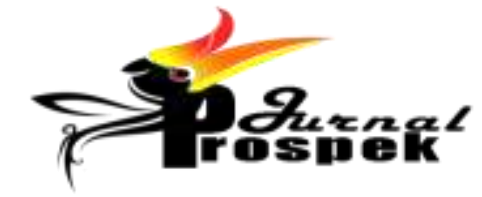

http://e-journals.unmul.ac.id/index.php/jpe

Jurnal Prospek : Pendidikan Ilmu Sosial dan Ekonomi

Volume 3 No 1 Juli 2021

E-ISSN 2721-0855

\section{PENDAHULUAN}

Produktivitas yang tinggi merupakan hal utama yang ingin dicapai oleh setiap perusahaan dalam setiap rencana yang ada. Dalam hal ini, peranan karyawan sangat pentingdan berarti. Namun demikian, perusahaan tidak dapat menafsirkan bahwa keterlibatan karyawan secara utuh dan efektif tidak akan berguna tanpa adanya loyalitas yang tinggi dari setiap karyawan yang terlibat dalam peningkatan produktivitas perusahaan. Karyawan yang baik dan bermutu adalah karyawan yang mampu memberikan segala kemampuan dan kesetian yang di milikinya kepada perusahaan. Hal ini akan terlihat dari seberapa besar perhatian yang di berikannya kepada perusahaan dalam bentuk pengabdian dan kinerja yang maksimal yang mampu mengantarkan perusahaan mewujudkan segala kemampuan. Namun, perusahaan tidak dapat mengindahkan bahwa segala pengabdian dan kerja keras yang telah di lakukan perusahaan harus di barengi dengan penghargaan dari perusahaan sebagai wujud dari perusahaan.

Salah satu bentuk penghargaan perusahaan terhadap para karyawannya adalah dalam bentuk promosi jabatan. Hal ini dilakukan guna memaksimalkan kualitas sumber daya manusia yang dimiliki dan berusaha untuk melakukan inovasi-inovasi bagi para karyawannya sehingga dapat bekerja dengan efektif dan efisien serta tidak menimbulkan kejenuhan dalam pekerjaan. Promosi Jabatan menurut Hasibuan (2003 : 173) merupakan proses pemindahan karyawan dari suatu jabatan ke jabatan lain yang lebih tinggi, yang biasanya diikuti oleh tugas, tanggung jawab, wewenang, dan penghasilan yang juga lebih tinggi dari jabatan yang diduduki sebelumnya. Dengan memberikan kesempatan promosi, berarti perusahaan melakukan usaha pengembangan karyawan melalui jenjang karir yang jelas, sehingga karyawan termotivasi untuk bekerja dan berprestasi sehingga kelangsungan operasional perusahaan akan lebih terjamin. Promosi jabatan yang dilakukan secara berkala oleh perusahaan diharapkan dapat berpengaruh pada peningkatan produktivitas kerja karyawan.

Sebagaimana organisasi lainnya, PT Nunukan Bara Sukses memberikan penghargaan kepada karyawan sebagai imbalan terhadap pengabdian dan kinerja kerja 


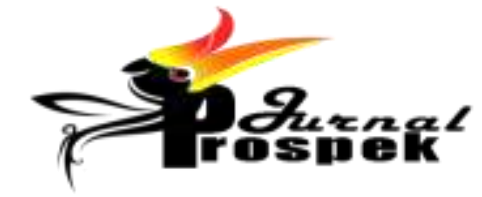

http://e-journals.unmul.ac.id/index.php/jpe

Jurnal Prospek : Pendidikan Ilmu Sosial dan Ekonomi

Volume 3 No 1 Juli 2021

E-ISSN 2721-0855

pegawai terhadap perusahaan dan promosi jabatan merupakan salah satu bentuk penghargaan perusahaan terhadap karyawan.

Sumber daya manusia yang berkualitas diperlukan oleh setiap perusahaan. Semakin berkembang perusahaan dan banyak sumber daya manusia yang dimilikinya, maka akan membutuhkan usaha lebih untuk mengaturnya. Oleh sebab itu, diperlukan manajemen SDM perusahaan yang bisa menjaga keseimbangan dan memanfaatkannya secara maksimal untuk menunjang produktifitas perusahaan. Dalam manajemen SDM, ada beberapa isu HR yang umum terjadi. Berikut lima di antaranya terbatasnya sumber daya dengan mutu skill yang tinggi, retensi sumber daya manusia, pengembangan sumber daya manusia.

Salah satu bentuk penghargaan yang dapat dilakukan adalah meningkatkan eksistensi dirinya melalui kesempatan memanfaatkan pengetahuan, keahlian, ketrampilan serta pengalaman dalam suatu bidang pekerjaan sehingga menghasilkan prestasi kerja. Atas dasar pertimbangan tersebut, perusahaan bisa memberikan balas jasa berupa materi maupun non materi salah satunya berupa promosi jabatan.

Menurut Anwar Prabu Mangkunegara (2009:67) mengemukakan bahwa: 'Kinerja adalah hasil kerja secara kualitas dan kuantitas yang dicapai oleh seorang pegawai dalam melaksanakan tugasnya sesuai dengan tanggung jawab yang diberikan kepadanyadi dalam pencapaian target dan tujuan organisasi tersebut tidak mudah, baik organisasi milik pemerintah atau milik swasta.

Di dalam mempertahankan dan meningkatkan produktivitas suatu perusahaan, maka peran manajemen sumber daya manusia sangatlah penting artinya dalam hal mengupayakan agar tenaga kerja mau dan mampu memberikan prestasi kerjanya sebaik mungkin. Dalam hal tersebut perusahaan berkewajiban memperhatikan kebutuhan karyawannya baik yang bersifat materil maupun yang bersifat non materil. Wujud dari perhatian, usaha serta dorongan yang dapat dilakukan oleh perusahaan terhadap karyawannya, salah satunya adalah dengan melaksanakan promosi jabatan yang objektif dan adil serta penempatan yang tepat. Jabatan merupakan tanggung jawab yang diemban setiap pegawai untuk melaksanakan tugas pekerjaannya. 


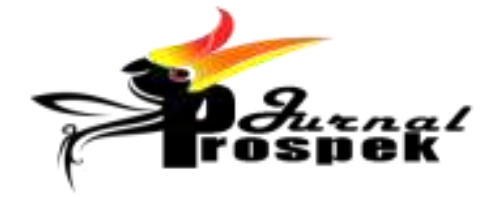

http://e-journals.unmul.ac.id/index.php/jpe

Jurnal Prospek : Pendidikan Ilmu Sosial dan Ekonomi

Volume 3 No 1 Juli 2021

E-ISSN 2721-0855

Perusahaan PT. Nunukan Bara Sukses Di Nunukan merupakan industri yang cukup besar bergerak dalam bidang produksi serta penjualan kelapa sawit dan banyak menyerap tenaga kerja untuk menjalankan kegiatan produksinya. Hal ini dilakukan agar perusahaan bisa memperoleh hasil yang maksimal dan menguntungkan bagi perusahaan. Untuk di perlukan produktivitas kerja karyawannya yang handal. Untuk dapat meningkatkan produktivitas kerja karyawannya, peranan promosi jabatan diduga sangat penting sekali, karena dengan kebijaksanaan tersebut dapat menjadi perangsang untuk meningkatkan semangat dan gairah kerja karyawan, sehingga karyawan dapat lebih terpacu untuk berprestasi. Selain itu juga promosi jabatan dapat dijalankan dengan baik maka tidak menutup kemungkinan efektivitas kerja karyawan juga akan meningkat.

Bagi perusahaan, prestasi kerja karyawan dapat menjadi tolak ukur produktivitas perusahaan sedangkan bagi karyawan produktivitas kerja dapat menunjukkan kemampuan dari tiap karyawan dalam melakukan kewajiban yang di bebankan perusahaan.Promosi jabatan yang diterapkan oleh perusahaan telah memberikan kontribusi yang positif kepada perusahaan. Karena selain dapat meningkatkan produktivitas kerja karyawan, promosi jabatan juga dapat meningkatkan kepuasan bagi para pengguna jasa perusahaan. Hal ini dikarenakan adanya sikap untuk menjadi yang terbaik dan memberikan hasil kerja yang maksimal dari para karyawan kepada perusahaan. Dari Promosi jabatan ini, diharapkan akan memotivasi karyawan untuk berprestasi yang akan berdampak pada produktivitas kerja karyawan dan produktivitas perusahaan untuk mencapai keuntungan. Berdasarkan uraian tersebut, tertarik untuk melakukan penelitian yang berjudul: "Hubungan promosi jabatan dengan produktivitas kerja karyawan pada PT. Nunukan Bara Sukses Di Nunukan 2020”.

Menurut Hasibuan (2010:16) Promosi mempunyai peranan penting bagi karyawan, bahkan menjadi idaman yang selalu dinanti-nantikan. Dengan promosi berarti ada kepercayaan dan pengakuan mengenai kemampuan serta kecakapan karyawan bersangkutan untuk menduduki suatu jabatan yang lebih tinggi. Dengan demikian, promosi akan memberikan status sosial, wewenang (authority), tanggung 


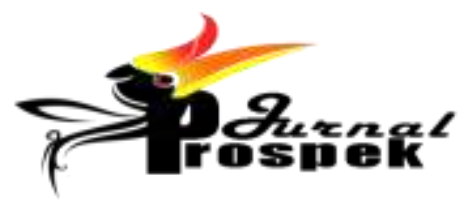

http://e-journals.unmul.ac.id/index.php/jpe

Jurnal Prospek : Pendidikan Ilmu Sosial dan Ekonomi

Volume 3 No 1 Juli 2021

E-ISSN 2721-0855

jawab (responsibility), serta penghasilan (autcome) yang semakin besar bagi karyawan.

Menurut Hasibuan (2013:108) mengungkapkan bahwa dimensi dan indikator promosi jabatan adalah sebagai berikut: 1) Kemampuan, 2) Kecakapan, 3) Tanggung Jawab. Menurut Basu Swastha (2013:281) bahwa, produktivitas adalah suatu konsep yang menggambarkan hubungan antara hasil (jumlah barang dan jasa yang diproduksi) dengan sumber (jumlah tenaga kerja, modal, tanah, energi, dan sebagainya) yang dipakai untuk menghasilkan hasil tersebut. Konsep produktivitas pada dasarnya dapat dilihat dari dua dimensi, yaitu dimensi individu dan dimensi organisasi.

Menurut Sedarmayanti (2013:612) indikator yang digunakan dalam pengukuran produktivitas kerja meliputi efektivitas dan efisiensi. Produktivitas Kerja adalah kemampuan menghasilkan barang dan jasa dari berbagai sumber daya atau faktor produksi yang digunakan untuk meningkatkan kualitas dan kuantitas pekerjaan yang dihasilkan dalam suatu perusahaan. PT. Nunukan Bara Sukses di Nunukan Tahun 2020. Tujuan penelitian ini adalah untuk mengetahuipromosi jabatan untuk mengetahui produktivitaskerjakaryawan dan untukmengetahuisignifikanantara promosi jabatan denganproduktivitas kerja karyawan.

\section{METODE}

Jenis penelitian yang digunkan adalah penelitian kuantitatif. Penelitian kuantitatif, sebagai metode penelitian yang berlandaskan pada fiosafat positivisme, digunakan meneliti pada populasi atau sampel tertentu, teknik pengambilan sampel pada umumnya dilakukan dengan cara random, pengumpulan data menggunakan instrumen penelitian , analisis data bersifat kuantitatif/statistik dengan tujuan untuk menguji hipotesis yang telah ditetapkan (Sugiyono,:2010:13).Pengumpulan data dalam penelitian ini dilakukan dengan observasi, Dokumentasi,Kuisioner. Analisi Data dalam penelitian ini menggunakan Korelasi Pearson Product Moment Menurut Ridwan dan Sunarto (2009, 80-81)Kegunaannya untuk mengetahui derajat hubungan dan kontribusi variabel bebas (independent) dengan variabel terikat (dependent). Tehnik analisis korelasi product moment termasuk tehnik parametik yang mengunakan data interval dan ratio dengan persyaratan tertentu. Misalnya data dipilih secara acak (random), datanya berdistribusi 


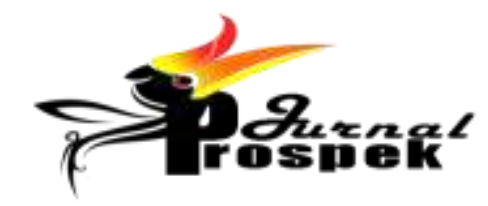

http://e-journals.unmul.ac.id/index.php/jpe

Jurnal Prospek : Pendidikan Ilmu Sosial dan Ekonomi

Volume 3 No 1 Juli 2021

E-ISSN 2721-0855

normal, data yang dihubungkan berpola linear dan data yang mempunyai hubungan pasangan yang sesuai dengan subjek yang sama.

\section{HASIL}

Tabel 1. Responden Data Jenis Kelamin dan Umur

\begin{tabular}{clccc}
\hline No & Jenis Kelamin & Umur & Keterangan & $\begin{array}{c}\text { Jumlah Tenaga } \\
\text { Kerja }\end{array}$ \\
\hline 1 & Laki-laki & $45-55$ & Mandor & 5 \\
\hline 2 & Perempuan & $33-35$ & Admin & 5 \\
\hline 3 & Laki-laki & 35 & Logistik & 7 \\
\hline 4 & Perempuan & $25-47$ & ACC & 5 \\
\hline 5 & Laki-laki Perempuan & $25-45$ & Buruh & 47 \\
\hline 6 & Laki-laki & $32-47$ & Driver & 8 \\
\hline & Jumlah & & & $\mathbf{7 7}$ \\
\hline
\end{tabular}

Sumber : Hasil Penelitian (2020)

Dari tabel diatas yang diidentifikasi bahwa responden dalam penelitian ini yang berjenis kelamin pria berjumlah 56 orang ( $72,7 \%)$, dan yang berjenis kelamin wanita berjumlah 21 orang ( $27,3 \%$ ). Dengan demikian, maka presentase terbesar dalam penelitian ini untuk jenis kelamin adalah pria dengan 56 orang responden atau $72,7 \%$.

Tabel 2. Responden Berdasarkan Lama Bekerja

\begin{tabular}{ccc}
\hline Lama Bekerja & Jumlah & Presentasi \\
\hline 0-5 Tahun & 7 & $9,1 \%$ \\
\hline 6-10 Tahun & 5 & $6,5 \%$ \\
\hline 11-15 Tahun & 5 & $6,5 \%$ \\
\hline$\geq 20$ Tahun & 31 & $40,3 \%$ \\
\hline Total & 29 & $37,7 \%$ \\
\hline
\end{tabular}

Sumber : Hasil Penelitian (2020)

Berdasarkan tabel diatas yang telah diidentifikasi bahwa responden dalam penelitian ini berdasarkan lama waktu bekerja $0-5$ tahun berjumlah 7 orang (9,1\%), waktu bekerja 6 - 10 tahun berjumlah 5 orang ( 6,5\%), waktu bekerja $11-15$ tahun berjumlah 5 orang ( 6,5\%), waktu bekerja 16 - 20 tahun berjumlah 31 orang ( 40,3\% ), dan waktu bekerja > 20 tahun berjumlah 29 orang (37,7\%). Dengan demikin, 


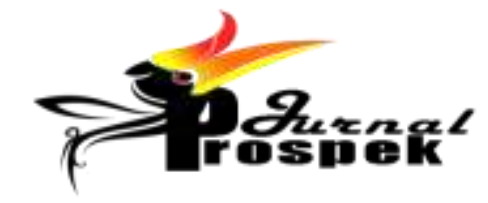

http://e-journals.unmul.ac.id/index.php/jpe

Jurnal Prospek : Pendidikan Ilmu Sosial dan Ekonomi

Volume 3 No 1 Juli 2021

E-ISSN 2721-0855

mayoritas tenaga pekerja dengan waktu bekerja 16 - 20 tahun mendominasi pekerjaan di bagian area.

Tabel 3. Promosi Jabatan PT. Nunukan Bara Sukses Tahun 2020 (X)

\begin{tabular}{cccc}
\hline Skor & Frekuensi & Persentase & Keterangan \\
\hline$\geq 70$ & 26 & 33,76 & Sangat baik \\
\hline$\leq 70$ & 51 & 66,24 & Baik \\
\hline Jumlah & $\mathbf{7 7}$ & $\mathbf{1 0 0}$ & \\
\hline
\end{tabular}

Sumber : Hasil Penelitian (2020)

Berdasarkan tabel diatas terlihat bahwa yang menyatakan tanggapan promosi seluruh karyawan sangat baik ada 26 orang yang menyatakan promosi karyawan baik ada 51 orang. Dari hasil perolehan tersebut dapat disimpulkan bahwa variabel promosi meliputi kemampuan, kecakapan dan tanggung jawab mendapatkan nilai baik.

Tabel 4. Produktivitas Kerja PT. Nunukan Bara Sukses Tahun 2020 (Y)

\begin{tabular}{cccc}
\hline Skor & Frekuensi & Persentase & Keterangan \\
\hline$\geq 70$ & 53 & 68,83 & Sangat baik \\
\hline$\leq 70$ & 24 & 31,17 & Baik \\
\hline Jumlah & $\mathbf{7 7}$ & $\mathbf{1 0 0}$ & \\
\hline
\end{tabular}

Sumber : Hasil Penelitian (2020)

Berdasarkan tabel diatas terlihat bahwa yang menyatakan tanggapan produktivitas kerja seluruh karyawan sangat baik ada 53 orang yang menyatakan produktivitas kerja baik ada 24 orang. Dari hasil perolehan tersebut dapat disimpulkan bahwa variabel produktivitas kerja meliputi Efektivitas dan efisiensi mendapatkan nilai sangat baik. Hasil analisis data menggunakan tehnik Product Moment untuk mengetahui ada atau tidak adanya antara hubungan variabel yang penulis teliti. Peneliti menggunakan dua variabel yaitu variabel promosi dan variabel produktivitas kerja karyawan sebagai variabel terikat. Hasil perhitungan korelasi Product Moment pada penelitian ini dapat dilihat sebagai berikut :

$$
r_{x y}=\frac{\Sigma x y}{\sqrt{\left(\Sigma x^{2}\right) \cdot\left(\Sigma y^{2}\right)}}
$$




$$
\begin{aligned}
& \mathrm{r}_{\mathrm{xy}}=\frac{375404}{\sqrt{366.168 \times 384.912}} \\
& \mathrm{r}_{\mathrm{xy}}=\frac{375.404}{\sqrt{140.942 .457 .216}} \\
& \mathrm{r}_{\mathrm{xy}}=\frac{375.404}{375.423} \\
& \mathrm{r}_{\mathrm{xy}}=0.999 \\
& \text { Eurnal Prospek : Pendidikan Ilmu Sosial dan Ekonomi } \\
& \text { Volume 3 No 1 Juli 2021 }
\end{aligned}
$$

Berdasarkan hasil perhitungan diatas, dapat dilihat bahwa $r_{\text {hitung }}>\mathrm{r}_{\text {tabelyaitu }} 0.999>$ 0.227Pada taraf signifikan 5\%, maka disimpulkan bahwa terdapat hubungan yang signifikan antara promosi jabatan dengan produktivitas kerja karyawan pada PT. Nunukan Bara Sukses Tahun 2020. Ini berarti Ho ditolak Ha diterima.

\section{PEMBAHASAN}

Berdasarkan hasil penelitian data penelitian dan analisis data mengenai kapabilitas promosi jabatan dengan produktivitas kerja karyawan PT. Nunukan Bara Sukses Tahun 2020. Dalam variabel promosi merupakan kesempatan untuk maju di dalam organisasi perusahaan Nunukan Bara Sukses sehingga memiliki peningkatan dalam jenjang karir, upah atau gaji juga kesejahteraan karyawan. Hubungan antara kapabilitas promosi dan produktivitas kerja karyawan PT. Nunukan Bara Sukses adalah bahwa produktivitas karyawan sangat berpengaruh terhadap promosi jabatan. Pelaksanaan penilaian produktivitas karyawan akan menghasilkan output atau prestasi kerja karyawan yang merupakan sarana untuk melihat kinerja dari karyawan. Dengan adanya pelaksanaa promosi jabatan akan membawa pada perbaikan kinerja dan produktivitas karyawan PT. Nunukan Bara Sukses yang lebih tinggi.Sejalan dengan pendapat Fathoni (2006), promosi jabatan merupakan perkembangan yang positif dari seorang pekerja atau pegawai karena tugasnya dinilai baik oleh pejabat yang berwenang. Jika ada kesempatan untuk dipromosikan bagi setiap karyawan yang berdasarkan atas asas keadilan dan objektivitas akan mendorong karyawan lebih giat, semangat, disiplin, dan berprestasi kerja yang semakinbesar sehingga sasaran perusahaan yang optimal dapat dicapai. 


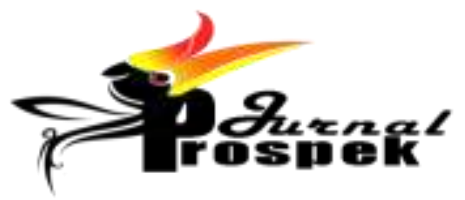

http://e-journals.unmul.ac.id/index.php/jpe

Jurnal Prospek : Pendidikan Ilmu Sosial dan Ekonomi

Volume 3 No 1 Juli 2021

E-ISSN 2721-0855

Promosi yang dilakukan PT. Nunukan Bara Sukses berpengaruh langsung terhadap produktivitas kerja, dikarenakan promosi yang dilakukan telah tersusun secara baik sehingga kenaikan posisi dan jabatan yang diberikan oleh perusahaan akan dapat diterima dengan mudah oleh para karyawan. Hasil ini menunjukkan bahwa promosi yang diselenggarakan dengan baik akan meningkatkan produktivitas kerja. Sedangkan Produktivitas kerja karyawan di PT. Nunukan Bara Sukses dinilai memiliki hubungan yang sangat baik dengan promosi karyawan. Hal ini dapat dilihat dari hasil penelitian yang sudah peneliti lakukan di PT. Nunukan Bara Sukses.Sementara itu Moekijat (2005)mengungkapkan Promosi adalah kemajuan yang diperoleh sebagai pegawai pada suatu tugas yang lebih baik, lebih baik dimaksud dipandang dari sudut tanggung jawab yang lebih berat martabat atau status yang lebih tinggi, kecakapan yang lebih baik, dan yang terpenting adalah penambahan jumlah gaji atau upah.

Berdasarkan hasil kuesioner data promosi jabatan, terdiri dari 3 indikator. Menurut Hasibuan (2013:108),yaitu 1) Kemampuan, 2) Kecakapan, 3) tanggung jawab sedangkan hasil kuisioner tingkat produktivitas karyawan, terdiri dari 2indikator,Menurut Sedarmayanti (2013:612), yaitu efektivitas dan efisiensi kerjatingkat produktivitas karyawanSehingga semua item pertanyaan memenuhi syarat atau dapat digunakan untuk penelitian selanjutnya dan mampu mewakili variabel yang diteliti. Berdasarkan penjelasan tentang penilaian terhadap variabel promosidirasakan oleh karyawan adalah sudah baik atau tinggi dan penilaian terhadap variabel produktivitas kerjadirasakan karyawan PT. Nunukan Bara Sukses adalah sudah baik atau tinggi sehingga promosi berpengaruh positif dan signifikan terhadap Produktivitas kerja. Karyawan yang memiliki tingkat kepuasan kerja yang tinggi terhadap pekerjaanya, secara tidak langsung akan mempengaruhi tingkat produktivitasnya, karena karyawan akan memperspesikan bahwa apa yang diberikan perusahaan kepadanya sudah wajar. Mereka akan memberikan hal yang setimpal kepada perusahaan dengan cara meningkatkan tingkat produktivitas kerja mereka

Dari berbagai macam promosi yang di lakukan oleh perusahaan penilaian kemampuan dan tanggung jawab dari karyawan PT. Nunukan Bara Sukses semakin baik sehingga 


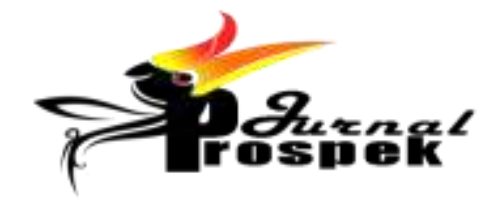

http://e-journals.unmul.ac.id/index.php/jpe

Jurnal Prospek : Pendidikan Ilmu Sosial dan Ekonomi

Volume 3 No 1 Juli 2021

E-ISSN 2721-0855

menghasilkan produktivitas dari efisiensi dan kuantitas kerja karyawan semakin baik dan tercapai tujuan yang diinginkan oleh perusahaan.

\section{KESIMPULAN}

1. Ada hubungan yang sangat kuat antara kapabilitas promosi jabatan dengan produktivitas kerja yang dianalisis dengan menggunakan $r$ hitung sebesar 0.999 yang artinya sangat kuat hubungan kapabilitas promosi jabatan dengan produktivitas kerja karyawan pada PT. Nunukan Bara Sukses Tahun 2020.

2. Berdasarkan hasil analisis koefisien korelasi product moment antara promosi jabatan (X) dengan produktivitas kerja (Y), dimana $r$ hitung adalah 0.999. Dalam hal ini bila di interprestasikan dengan tabel interprestasi nilai rsesuai dengan yang diungkapkan oleh Ridwan dan Sunarto (2009). Berarti variabel promosi jabatan dengan produktivitas kerja memiliki hubungan dalam kategori "sangat kuat". Dilihat dari perbandingan antara nilai $r_{\text {hitung dengan }} r_{\text {tabel }}$, dengan taraf signifikansi $5 \%$ yaitu $\mathrm{N}=$ 77 adalah 0.227 dimana $r$ hitung $(0.999)>r_{\text {tabel }}(0.227)$, maka dapat diambil kesimpulan bahwa ada hubungan antara kapabilitas promosi jabatan dengan produktivitas kerja karyawan pada PT. Nunukan Bara Sukses Tahun 2020. Dengan demikian Ha atau hipotesis yang peneliti ajukan dalam penelitian ini diterima. 


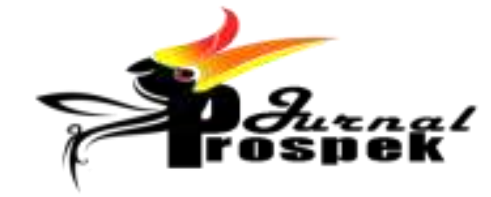

http://e-journals.unmul.ac.id/index.php/jpe

Jurnal Prospek : Pendidikan Ilmu Sosial dan Ekonomi

Volume 3 No 1 Juli 2021

E-ISSN 2721-0855

\section{DAFTAR PUSTAKA}

Basu,S, 2010.Manajemen Penjualan: Pelaksanaan Penjualan, BPFE-. Yogyakarta

Fathoni. Abdurrahmat, 2006. Manajemen Sumber Daya Manusia. Bandung: Rineka Cipta.

Hasibuan, M. 2003. Organisasi dan Motivasi Dasar Peningkatan Produktivitas. Jakarta: Bumi Aksara

Hasibuan, M.2010.Manajemen Sumber Daya Manusia. Jakarta: Bumi Aksara.

Hasibuan, M. 2013. Manajemen Sumber Daya Manusia. Jakarta: PT Bumi Aksara

Mangkunegara,A.P. 2009. Evaluasi Kinerja Sumber Daya Manusia.Bandung: Penerbit Refika Aditama.

Moekijat. 2005. Manajemen personalia dan sumber daya manusia. Bandung: Mandar Maju.

Ridwan\& Sunarto. 2009. Pengantar Statistika. Bandung:Alfabeta.

Sedarmayanti. 2013. Manajemen Sumber Daya Manusia, Reformasi Birokrasi dan Manajemen Pegawai Negeri Sipil. Bandung: Refika Aditama

Sugiyono. 2010. Metode Penelitian Pendidikan Pendekatan Kuantitatif, kualitatif, dan R\&D. Bandung: Alfabeta 